\title{
Activity of Energy and Carbohydrate Metabolism Enzymes in the Juvenile Pink Salmon Oncorhynchus gorbuscha (Walb.) during the Transition from Freshwater to a Marine Environment
}

\author{
M. V. Churova ${ }^{a,}$, N. S. Shulgina ${ }^{a}$, M. Yu. Krupnova ${ }^{a}$, D. A. Efremov ${ }^{a}$, and N. N. Nemova ${ }^{a}$ \\ ${ }^{a}$ Institute of Biology, Karelian Research Center, Russian Academy of Sciences, Petrozavodsk, 185910 Russia \\ *e-mail: mchurova@yandex.ru
}

Received July 3, 2020; revised September 10, 2020; accepted September 10, 2020

\begin{abstract}
Biochemical adaptations of energy metabolism and some pathways of glucose oxidation during a change in salinity of the environment in larvae and smolts of the pink salmon Oncorhynchus gorbuscha (Walb.) inhabiting the White Sea were studied. We assayed the activity of energy and carbohydrate metabolism enzymes (cytochrome $c$ oxidase (COX), lactate dehydrogenase (LDH), glucose-6-phosphate dehydrogenase (G6PDH), 1-glycerophosphate dehydrogenase (1-GPDH), and aldolase) in pink salmon larvae in a short-term aquarium experiment and in pink salmon smolts in a long-term cage experiment simulating the transition of juveniles from freshwater to a marine environment. A decrease in the activity of COX, LDH, 1-GPDH, and aldolase already in the first hour after the transfer of larvae to seawater was shown. Smolts kept in the estuary and in the sea had low levels of activity of 1-GPDH and aldolase in comparison with individuals from the river. Most likely, in the salmon juveniles studied, there was a redistribution of carbohydrates between the reactions of aerobic and anaerobic metabolism in favor of anaerobic ATP synthesis. No changes in the enzyme activity of the pentose phosphate pathway, G-6-PDH, were found in either larvae or smolts compared with the individuals kept in freshwater. Maintenance of the required levels of anaerobic metabolism and of the pentose phosphate pathway is probably one of the mechanisms of biochemical adaptation of pink salmon to changes in salinity.
\end{abstract}

DOI: $10.1134 / \mathrm{S} 106235902104004 \mathrm{X}$

\section{INTRODUCTION}

The life cycle of salmonids includes various stages of development with a complex system of adaptations. The smoltification stage is a genetically programmed process during which salmon living in freshwater physiologically prepare for migration to the sea and life under conditions of increased salinity (McCormick, 2012). In the majority of salmonids, the period before the beginning of smoltification may last up to several years, whereas smolts of the pink salmon O. gorbuscha (Walb.) migrate to the sea immediately after emerging from the bottom in the state of fry, leaving relatively little time for smoltification (Grant et al., $2009,2010)$. Due to the small size of smolts $(0.2 \mathrm{~g})$ during the migration period, the large ratio of the surface area of the body to its volume additionally complicates the maintenance of the ionic and water balance in seawater. However, it was shown (Weisbart, 1967) that, at the earliest stage of life, pink salmon smolts can regulate ions in the blood plasma upon the drastic transition to seawater better than other Pacific salmon of the genus Oncorhynchus. For example, fry of the sockeye salmon Oncorhynchus nerka (Walb.), coho salmon Oncorhynchus kisutch (Walb.), and chinook salmon Oncorhynchus tshawytscha (Walb.) that did not undergo smoltification died after being transferred to seawater, whereas fry of pink salmon adapted to the new conditions (Weisbart, 1967; Grant et al., 2009). Earlier, using migrating pink salmon smolts $(0.2 \mathrm{~g})$, it was shown that, when they were transferred to salt water, the concentration of $\mathrm{Na}^{+}$and $\mathrm{Cl}^{-}$in their body (per gram fresh weight) increased and for some time remained at the same level (up to two weeks). The authors explain this by the fact that an increase in the ion concentration in the body is an adaptation strategy of the species aimed at reducing the ionic gradient with the environment (Grant et al., 2009, 2010). However, dehydration in juvenile pink salmon was not observed, and the activity of $\mathrm{Na}^{+} / \mathrm{K}^{+}$-ATPase (the main osmoregulatory enzyme) to the maximum level increased gradually rather than immediately, for some time after the change in salinity (Grant et al., 2009, 2010). However, research data on the biochemical mechanisms that ensure the rearrangement of metabolic processes in pink salmon are still insufficient. 
It is known that the processes of fish adaptation to changes in the salinity of the environment, mediated by glucocorticoid hormones such as cortisol (McCormick, 2001), include changes in the osmoregulatory system and redistribution of energy resources (Soengas et al., 2007; Ruiz and Jarabo, 2019). Data of studies on the intensity of oxygen consumption in fish with changes in the salinity of the environment indicate an increase in energy consumption for modulation and stimulation of ion transport processes (Soengas et al., 2007; Tseng, 2008). The rearrangement of metabolism in general and changes in the intensity and direction of the pathways of energy and carbohydrate metabolism, in particular, are aimed at meeting the increased energy requirements of juvenile fishes associated with their acclimatization to salinity. It was shown that the energy required for the osmoregulatory organs of fishes (including the gills and kidneys) is primarily maintained due to oxidation of glucose and lactate coming from the bloodstream (Tseng, 2008). Energy expenditures for the regulation of metabolism upon changes in the salinity of the environment can be analyzed in two ways: (1) by assessment of the total metabolism by the degree of oxygen uptake and (2) by assessment of changes in the amount of energy substrates or the activity of enzymes that control their metabolism (Soengas et al., 2007). The energy status and functional activity of fish organs can be assessed by the activity of the key enzymes of aerobic and anaerobic ATP synthesis, which are the main pathways of glucose oxidation. For example, $\mathrm{CO}$ is a key enzyme of the mitochondrial respiratory chain, the activity of which indicates the level of aerobic metabolism (Goolish and Adelman, 1987). LDH, a glycolytic enzyme, can serve as an indicator of anaerobic metabolism (Gauthier et al., 2008). The activity of aldolase characterizes the degree of utilization of carbohydrates in glycolysis (Johansen and Overturf, 2006). 1-GPDH catalyzes the formation of 1-glycerophosphate, which is a precursor of structural and storage lipids. G6PDH is involved in the functioning of the pentose phosphate pathway (PPP) (Tian et al., 1998). Differences in the nature of changes in the activity of these enzymes during adaptation to salinity were shown earlier in studies on euryhaline and anadromous fishes (Sangiao-Alvarellos et al., 2003; Le François and Blier, 2003; Le François et al., 2004; Churova et al., 2018).

Taking into account the peculiarities of physiological and biochemical adaptations in pink salmon that are associated with the migration of fry to the marine environment immediately after emerging from the bottom, which requires a relatively quick response of the body to the change in the salinity of the environment, it can be assumed that this process is energetically ensure by a change in the direction and intensity of pathways of energy metabolism and glucose oxidation. It is necessary to find out how the substrates are distributed between the aerobic and anaerobic pathways of energy metabolism, i.e., the pentose phosphate pathway, as well as to assess the plasticity (reversibility of changes) of the above-mentioned reactions after pink salmon fry are transferred from freshwater back to seawater.

Thus, the aim of this work was to study the activity of enzymes of energy and carbohydrate metabolism (cytochrome $c$ oxidase, lactate dehydrogenase, glucose-6-phosphate dehydrogenase, 1-glycerophosphate dehydrogenase, and aldolase) in larvae and smolts of the pink salmon Oncorhynchus gorbuscha (Walb.) upon a change in salinity in short-term aquarium and long-term cage experiments. To achieve this goal and test the above hypothesis, two experiments were conducted to study the adaptive capabilities of pink salmon smolts to changes in the salinity of the environment at an early stage (larva that emerged from the nest) and smolts during downstream migration. The first (short-term) experiment was aimed at studying the resistance of pink salmon larvae to their transfer to seawater and the plasticity of the response after their return to freshwater. In the second (long-term) experiment, the biochemical adaptations of smolts in areas of their downstream migration with different salinity (rivers, estuary, and sea) were studied in a comparative aspect.

\section{MATERIALS AND METHODS}

A Short-Term Aquarium Experiment on the Effect of the Change in Salinity on Pink Salmon Larvae (after Their Transfer from Freshwater to Seawater)

The experiment was performed with pink salmon larvae from a spawning nest found on June 20 in the Olkhovka River (White Sea basin) (Fig. 1). The remainder of the yolk sac in the larvae at this time was $10-15 \%$. In all experiments, pink salmon smolts were fixed in liquid nitrogen and then stored at $-80^{\circ} \mathrm{C}$ until the start of the analysis.

The collected larvae were placed in a cage in the same river. The aquarium experiment was started on June 21. The fish from the cage were divided into two groups, 20 individuals from the first group were fixed for analysis (control), and fish of the second group were placed in a container with seawater at a water temperature of $14.6^{\circ} \mathrm{C}$. Then, after $1 \mathrm{~h}$ of incubation, 20 individuals were caught and fixed. After $24 \mathrm{~h}$ of incubation, another 20 fish were withdrawn for analysis. The remaining larvae were transferred into a nearby container with freshwater and fixed in $24 \mathrm{~h}$. During the experiment, air was supplied to the container with pink salmon fry using a Sera air 275R compressor. The size and weight characteristics of fish are 


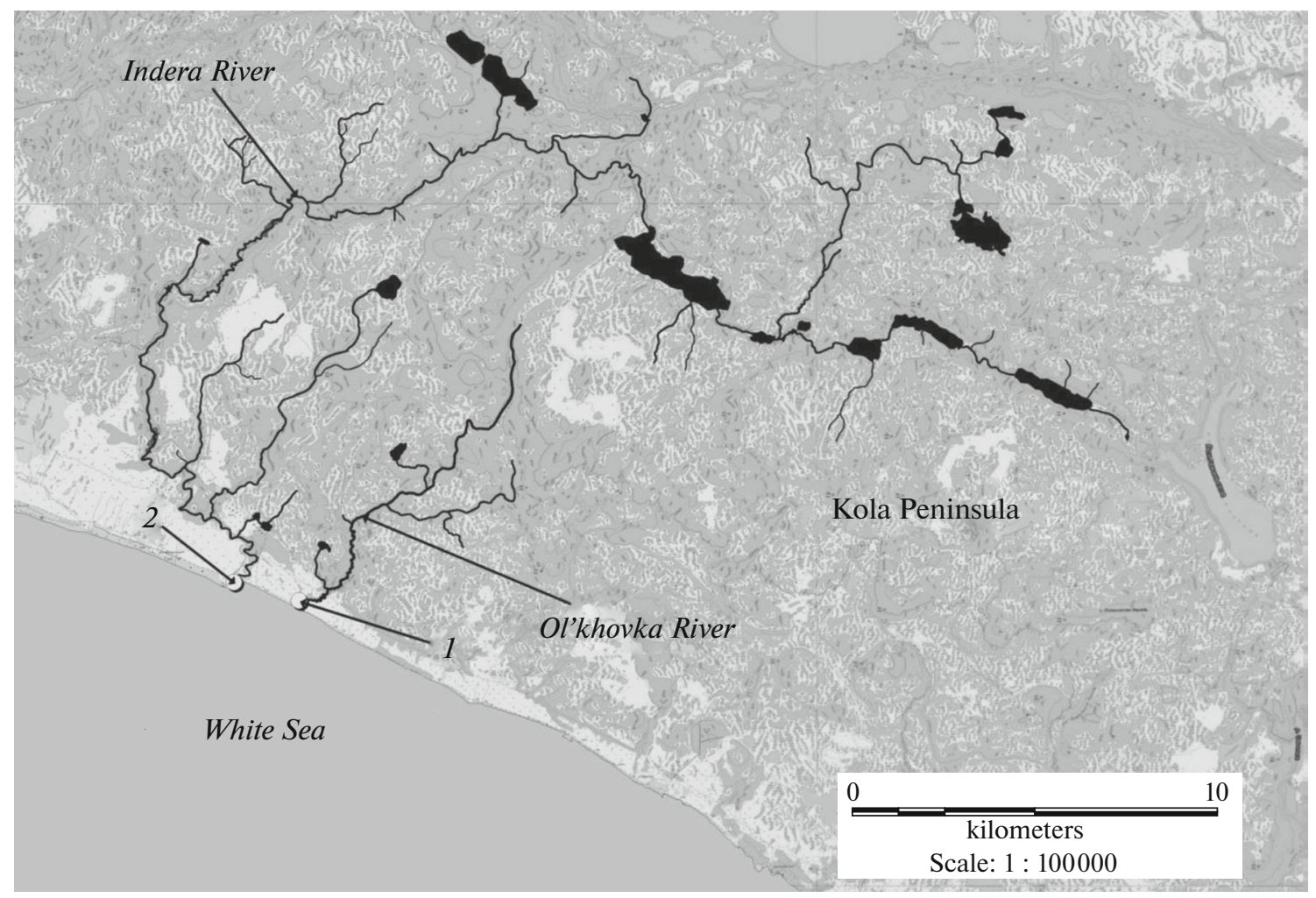

Fig. 1. Sites of sample collection and the experiment: (1) site of catching pink salmon larvae; (2) site of the cage experiment.

summarized in Table 1. No death of larvae during the experiment was observed.

\section{Long-Term Cage Experiment on the Effect} of the Transfer of Pink Salmon Smolts from Freshwater to the Estuary and to the Sea

On June 14, 100 pink salmon smolts were caught with a small trap net in the Indera River (White Sea basin) at a water temperature of $8.8^{\circ} \mathrm{C}$. Then, the fry were divided into four groups of 25 individuals each (Fig. 2). The first group was fixed for further analysis (control). The second group was placed in a channel cage in freshwater (cage "river"), which was submerged in water by $60 \%$ (flow speed, $0.3-0.4 \mathrm{~m} / \mathrm{s}$ ) at a temperature of $8.8^{\circ} \mathrm{C}$. The experiment was completed on June 24 at a water temperature of $14.5^{\circ} \mathrm{C}$, when the samples were taken and fixed for further analysis. The third group of smolts was placed in a sea cage (cage "sea") with a water salinity of $28 \%$ (constant) and a temperature of $3.9^{\circ} \mathrm{C}$. The smolts were preliminarily incubated in a freshwater : seawater mixture $(1: 1)$ for $1 \mathrm{~h}$ and then in $100 \%$ seawater for another $1 \mathrm{~h}$. The cage was placed $400 \mathrm{~m}$ from the coast at a depth of $4-5 \mathrm{~m}$, at a distance of $1 \mathrm{~m}$ from the bottom on guy lines and was in the water column regardless of the tide. The samples for biochemical analysis were collected on June 24 at a water temperature of $11.5^{\circ} \mathrm{C}$.

The fourth group was placed in a cage in the estuary (cage "estuary") on June 14. However, the experiment was interrupted by the actions of third parties (force majeure). For this reason, the experiment with the estuary cage was repeated on June 17. At low tide,

Table 1. Size and weight characteristics of pink salmon larvae in the aquarium (short-term) experiment

\begin{tabular}{l|c|c}
\hline \multicolumn{1}{c|}{ Group } & Length (AB), cm & Weight, g \\
\hline Control & $3.2 \pm 0.03$ & $0.14 \pm 0.004$ \\
Seawater, 1 h & $3.16 \pm 0.03$ & $0.14 \pm 0.002$ \\
Seawater, 24 h & $3.18 \pm 0.04$ & $0.14 \pm 0.009$ \\
Return to freshwater & $3.2 \pm 0.02$ & $0.14 \pm 0.001$ \\
\hline
\end{tabular}



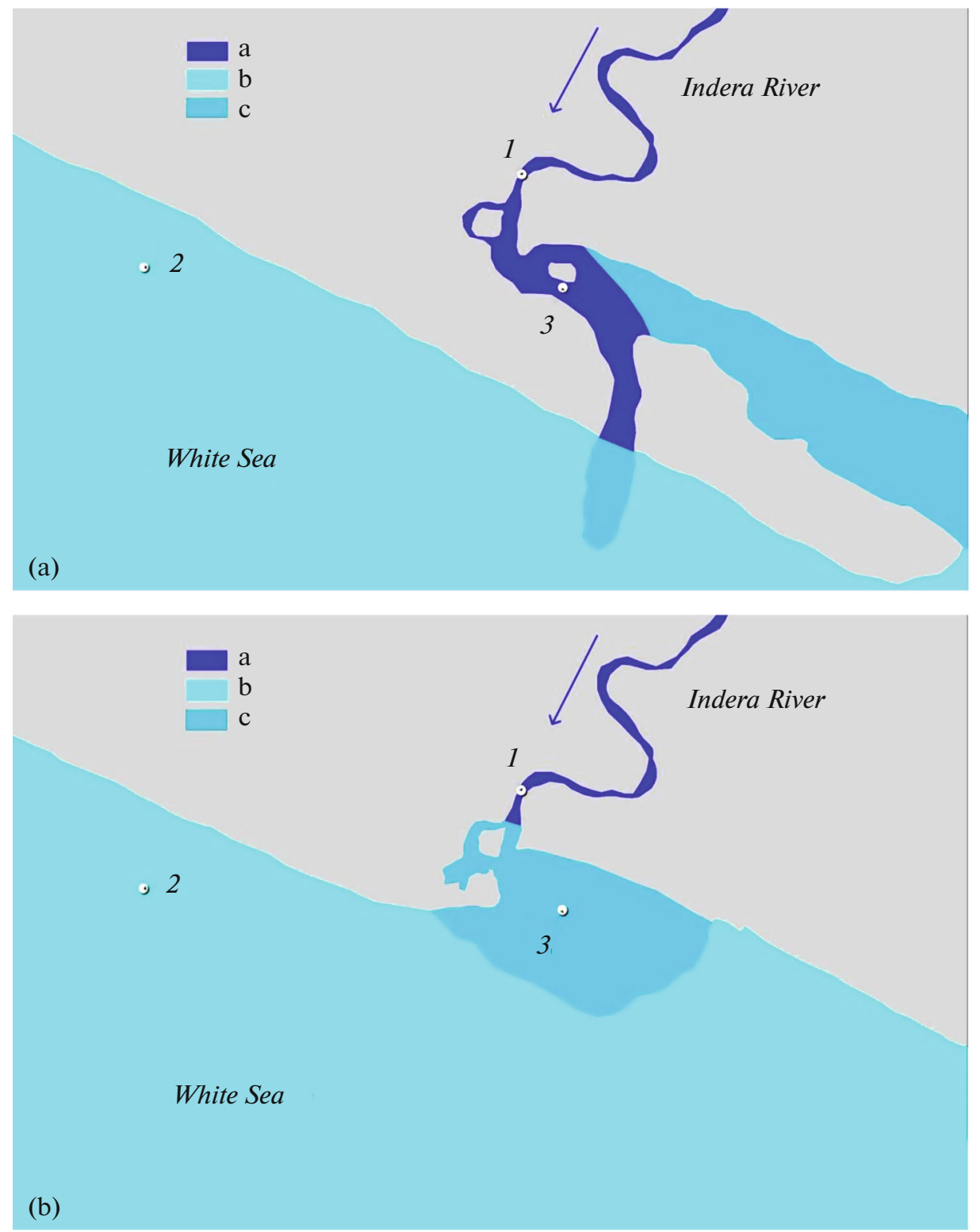

Fig. 2. Position of the experimental cages in the Indera River estuary (a) at low tide and (b) at high tide: (1) cage in freshwater; (2) cage in seawater; (3) cage in the estuary. Designations: a, freshwater; b, salt water; c, brackish water; dry land is shown in gray.

the cage was in a stream of freshwater at a water temperature of $8.8^{\circ} \mathrm{C}$ and was submerged by $50 \%$ (flow speed, $0.3-0.4 \mathrm{~m} / \mathrm{s})$. During the high tide, the cage was submerged in water at a distance of $0.4-0.5 \mathrm{~m}$ from the bottom, the water was salty/freshened (depending on the wind direction and local current). Twice a day, during full high tide and full low tide, the cage was in water with a cycle of fresh/salt/fresh/salt water, etc., every $24 \mathrm{~h}$. At the same time, the water temperature changed, freshwater warmed up faster, and salt water warmed up more slowly; with each tide, the water became cold, and with each ebb it became warm (amplitude, up to $10^{\circ} \mathrm{C}$ ). The experiment was completed June 27, 2018, at a water temperature of $18.1^{\circ} \mathrm{C}$ at low tide.

The duration of exposure for the second, third, and fourth groups was 9 days 11 hours (in total, $226 \mathrm{~h}$ ). No death of smolts was observed during the study. The size and weight characteristics of fish are summarized in Table 2.

The activity of energy and carbohydrate metabolism enzymes was determined individually for each specimen. The activity of cytochrome $c$ oxidase (EC 1.9.3.1) was determined according to Smith (Smith, 1955) by measuring the increase in the amount of oxidized cytochrome $c$. The total activity of 
Table 2. Size and weight characteristics of pink salmon smolts in the cage (long-term) experiment

\begin{tabular}{l|c|c|c}
\hline \multicolumn{1}{c|}{ Group } & $\begin{array}{c}T,{ }^{\circ} \mathrm{C} \\
\text { (on the day of collection) }\end{array}$ & Length (AB), cm & Weight, g \\
\hline June 14, before experiment, river & 8.8 & $3.35 \pm 0.06$ & $0.17 \pm 0.013$ \\
June 24, river & 14.5 & $3.53 \pm 0.03$ & $0.16 \pm 0.010$ \\
June 27, estuary & 18.1 & $3.51 \pm 0.05$ & $0.19 \pm 0.007$ \\
June 24, sea & 11.5 & $3.41 \pm 0.02$ & $0.17 \pm 0.006$ \\
\hline
\end{tabular}

lactate dehydrogenase (LDH, 1.1.1.27), glucose-6phosphate dehydrogenase (G6PDH, 1.1.1.49), and 1glycerophosphate dehydrogenase (1-GPDH, 1.1.1.49) was determined by measuring the amount of reduced NAD and NADP by the generally accepted methods (Kochetov, 1980). The activity of aldolase (EC 4.1.2.13) was determined by the Beck method modified by Anan'ev and Obukhova (Kolb and Kamyshnikov, 1976). Enzyme activities were presented in $\mu \mathrm{mol} / \mathrm{min}$ per $\mathrm{mg}$ protein. The protein concentration was determined spectrophotometrically by the peptide bond absorption at $220 \mathrm{~nm}$ (Noble and Bailey, 2009). The results were processed statistically using the Kruskal-Wallis test with subsequent comparison of the samples using the Mann-Whitney test. Differences were considered significant at $p<0.05$. The studies were conducted using the equipment of the Core Facility of the Karelian Research Center, Russian Academy of Sciences.

\section{RESULTS AND DISCUSSION}

\section{Activity of the Enzymes Studied in Pink Salmon Larvae after Transfer from Freshwater to Seawater (Short-Term Aquarium Experiment)}

Data indicating differences in the changes in the activity of the enzymes of energy and carbohydrate metabolism studied in pink salmon larvae after their direct transfer from freshwater to seawater were obtained. It was shown that the activities of the enzymes $\mathrm{CO}, \mathrm{LDH}, 1-\mathrm{GPDH}$, and aldolase actually decreased in the first hour after the transfer of individuals to seawater (Fig. 3), which indicates both a decrease in aerobic and anaerobic metabolism and a decrease in the use of carbohydrates in glycolysis and in the synthesis of glycerophosphate (in particular). As was shown earlier by Grant et al. (2009, 2010), the transfer of pink salmon smolts to salt water is accompanied by an increase in the concentration of $\mathrm{Na}^{+}$and $\mathrm{Cl}^{-}$in the body, which remained at the same level for some time (up to two weeks); the activity of $\mathrm{Na}^{+} / \mathrm{K}^{+}-$ ATPase to the maximum level increased gradually. In our experiment, the activity of $\mathrm{Na}^{+} / \mathrm{K}^{+}$-ATPase in pink salmon larvae after their transfer to seawater (Käiväinen et al., unpublished data) gradually increased after $1 \mathrm{~h}$ of the experiment and then after one day. The aforementioned decrease in the activity of the enzymes of energy and carbohydrate metabolism in pink salmon larvae with a sharp increase in the concentration of ions in the body is, apparently, consistent with triggering the mechanisms of energy redistribution between osmoregulation and other energyconsuming metabolic processes such as growth and development (Sangiao-Alvarellos et al., 2003; Le Francois et al., 2004).

Since the activity of LDH, 1-GPDH, and aldolase (Figs. 3b, 3d, 3e) in larvae after their return to freshwater returned to the initial level, the plasticity of the response of the metabolic pathways studied to a drastic change in salinity/desalination can be postulated. The activity of $\mathrm{CO}$ (enzyme of aerobic metabolism) increased insignificantly.

The activity of the pentose phosphate pathway enzyme G6PDH in pink salmon larvae did not change throughout the experiment (Fig. 3c), which is consistent with the published data (Soengas et al., 1993) on the absence of changes in G6PDH activity in the muscles of juvenile trout transferred to seawater. Most likely, the maintenance of the activity of the pentose phosphate pathway is necessary to maintain the level of NADPH, which is used in the reactions of biosynthesis of fatty acids, cholesterol, steroid hormones, and sphingolipids (Tian et al., 1998). Under hyperosmotic shock conditions, the synthesis of steroids is activated, including the steroid hormones that are involved in the regulation of osmoregulatory mechanisms (McCormick, 2001; Ruiz-Jarabo et al., 2019).

\section{Activity of the Enzymes Studied in Pink Salmon Smolts Kept in the River, Estuary, and Sea (Long-Term Cage Experiment)}

In the cage experiment, the $\mathrm{CO}$ activity in pink salmon smolts kept in the estuary and in the sea decreased as compared to the individuals that remained in freshwater (Fig. 4a), which is consistent with the above data from the short-term aquarium experiment on the decrease in the activity of the aerobic metabolism enzyme after the transfer of larvae to seawater. Earlier, in a study on young chars (Salvelinus fontinalis) $1+$, it was also shown that their transfer 

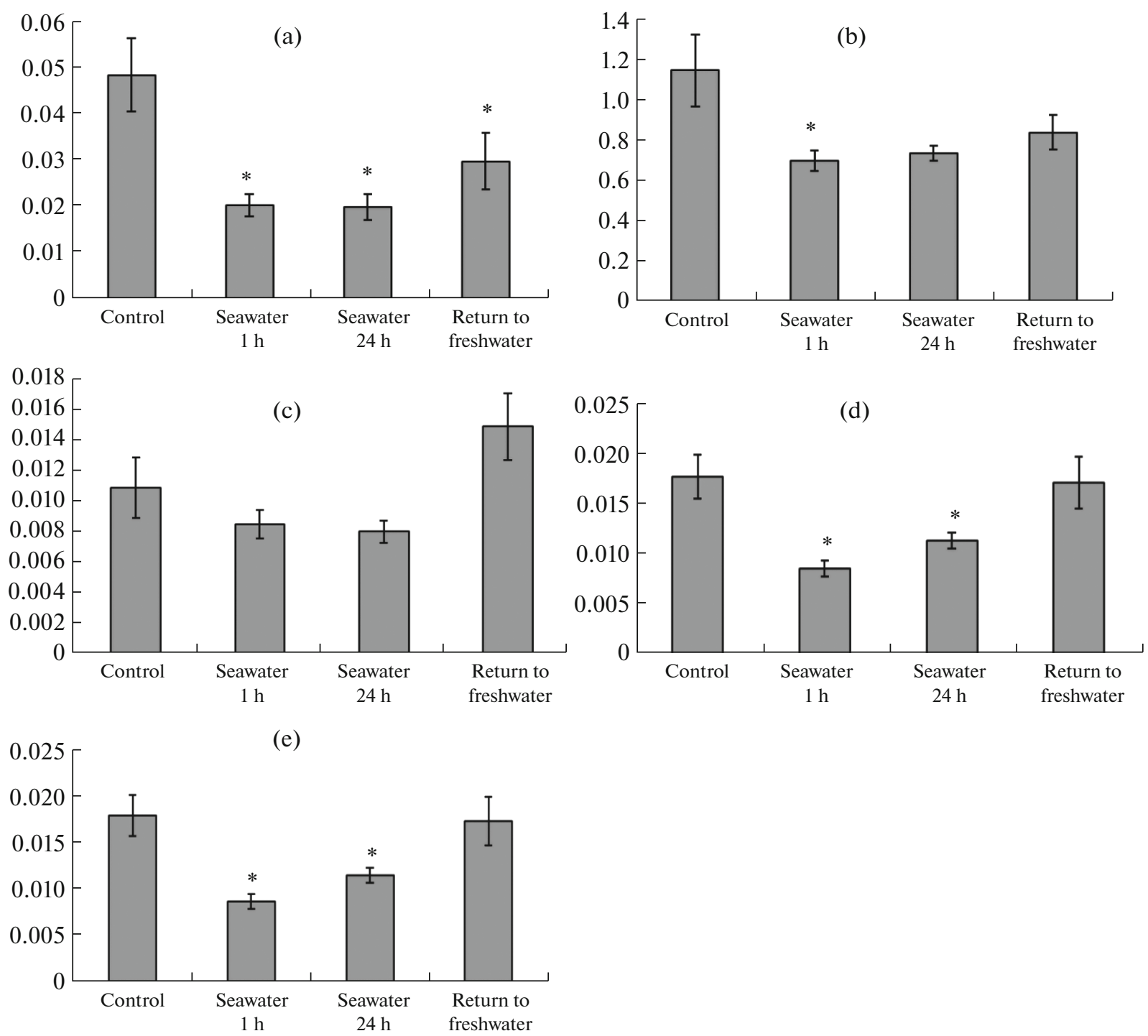

Fig. 3. Relative activity of the enzymes (a) CO, (b) LDH, (c) G6PDH, (d) 1-GPDH, and (e) aldolase ( $\mu \mathrm{mol} / \mathrm{min}$ per mg protein) in pink salmon larvae transferred to seawater in the short-term experiment. * Differences from the control were significant at $p<0.05$.

from freshwater to seawater for one month led to a decrease in the $\mathrm{CO}$ activity in the gills against the background of an increase in activity of $\mathrm{Na}^{+} / \mathrm{K}^{+}-$ ATPase (Le Francois and Blier, 2003). In the spotted catfish juveniles $(1+)$ that were kept for 14 and 19 weeks in water of varying salinity $(7,14,21$, and $28 \%$ ), low CO activity in the gills was detected in the medium with the lowest salinity (7\%o); at other concentrations, no difference was observed. No correlation between the changes in the activity of $\mathrm{Na}^{+} / \mathrm{K}^{+}$ATPase and CO was found (Le Francois et al., 2004). It is believed (Le Francois et al., 2004) that, in different fish species, there are certain differences in the regulation of $\mathrm{CO}$ activity with changes in salinity.

The low aerobic capacity in pink salmon smolts in the sea and in the estuary is, apparently, compensated for by anaerobic synthesis of ATP, which is indicated by the absence of differences in the level of LDH activity in these groups of fish, as compared with that in the individuals from the river channel (Fig. 4b), against the background of a decrease in the $\mathrm{CO}$ activity. According to the published data (Tseng and Hwang, 2008), anaerobic carbohydrate metabolism plays the key role in the adaptive responses of water-salt metabolism to life in seawater, being a mechanism that responds quickly to changes in the demand for energy of ATP. For example, the studies of the adaptation of wolffish fry to different salinity conditions $(7,14,21$, and $28 \% \circ$ ) showed that, along with an increase in the activity of $\mathrm{Na}^{+} / \mathrm{K}^{+}$-ATPase, the activity of $\mathrm{LDH}$ and pyruvate kinase (PK) also increased (Le Francois et al., 2004). The study of the sensitivity of mature 
(a)

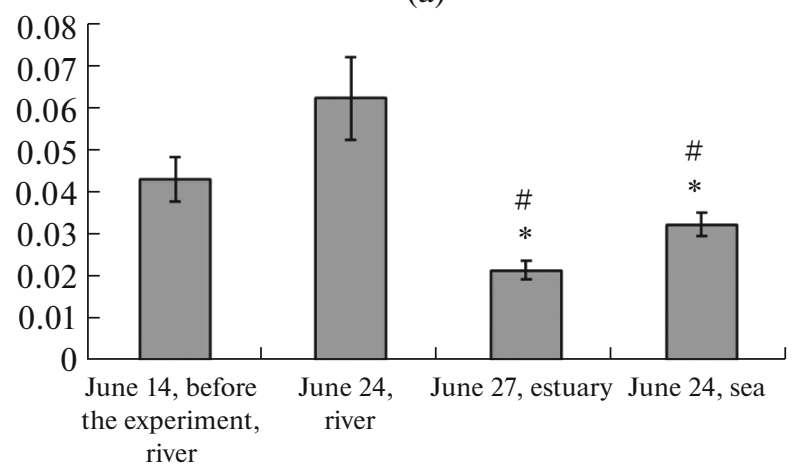

(c)

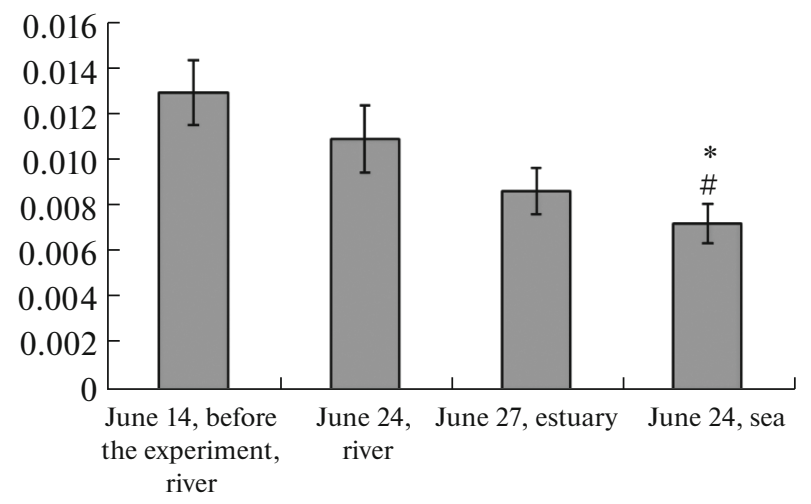

(e)

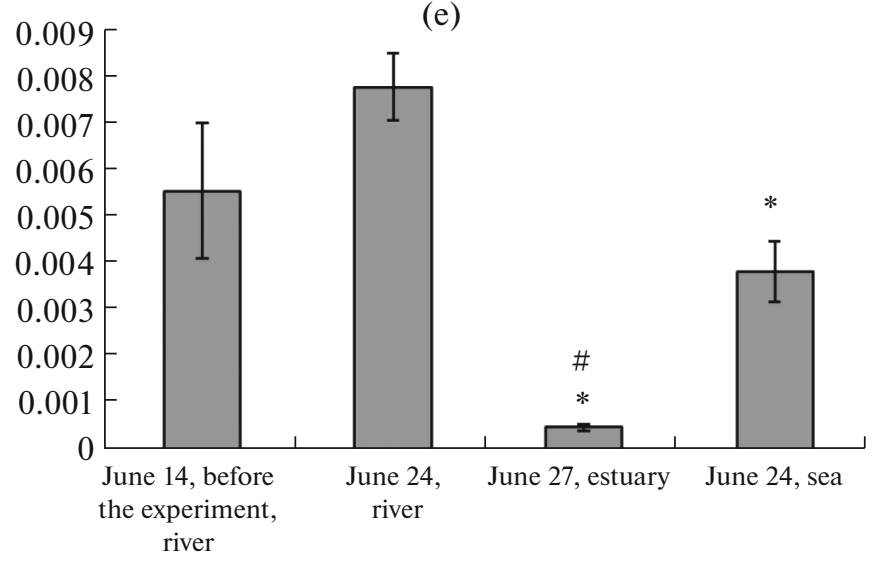

(b)

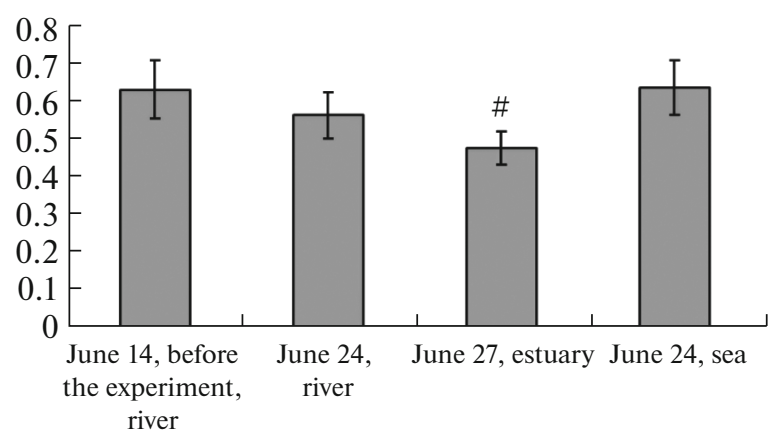

(d)

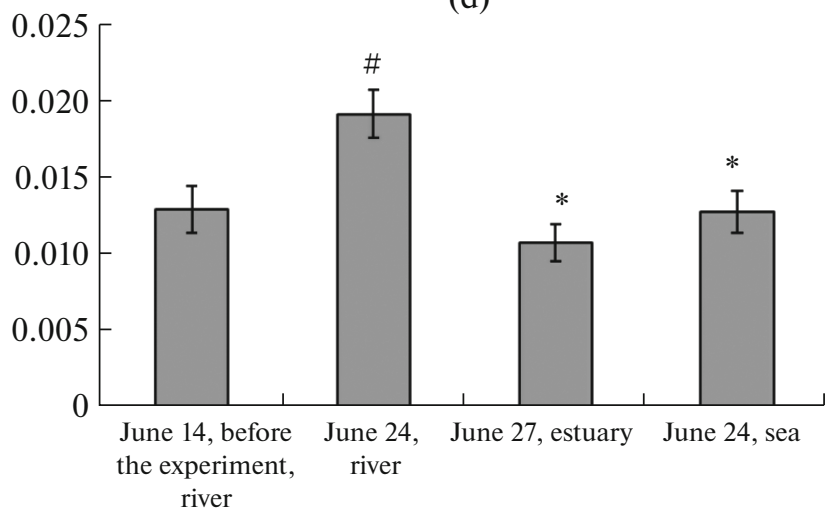

Fig. 4. Relative activity of the enzymes (a) CO, (b) LDH, (c) G6PDH, (d) 1-GPDH, and (e) aldolase ( $\mu \mathrm{mol} / \mathrm{min}$ per mg protein) in pink salmon smolts kept in the estuary and in the sea in the long-term experiment. * Differences from the data "June 24 , river" were significant at $p<0.05$; \# differences from the data "June 14, before the experiment" were significant at $p<0.05$.

S. fontinalis individuals to changes in salinity during the reproductive period showed that the changes in the activity of $\mathrm{Na}^{+} / \mathrm{K}^{+}$-ATPase in the gills during incubation in seawater were not associated with changes in the activity of PC and $\mathrm{LDH}$, whereas in sterile, immature individuals, the activity of both LDH and $\mathrm{Na}^{+} / \mathrm{K}^{+}$-ATPase in the gills was higher in seawater (Le Francois and Blier, 2003, Le Francois et al., 2004). The importance of anaerobic metabolism (glycolysis) in fishes in the energy supply upon changes in the salinity of the environment is evidenced by the increase in the level of oxidation of glucose and lactate, which become the main sources of energy during the adaptation of different fish species to salinity (Soengas et al., 2007).

In the individuals kept in the estuary and in the sea, as compared to the those from the river, low levels of 1-GPDH and aldolase activity were detected 
(Figs. 4c, 4d), which is also consistent with the results of the short-term aquarium experiment on pink salmon larvae (Figs. 3c, 3d). This indicates a decrease in the use of carbohydrates in glycolysis and glycerophosphate synthesis in smolts. Since the activity of CO decreases and the activity of LDH does not change, it is likely that carbohydrates in the young pink salmon under study are redistributed between the reactions of aerobic and anaerobic metabolism in favor of anaerobic ATP synthesis. The lowest level of aldolase activity in juvenile pink salmon in the estuary is also worth noting. In the estuary, smolts are more susceptible to changing conditions (change in fresh and salt water, temperatures, and flow speed). It is likely that the pink salmon smolts under the estuarine conditions have the greatest expenditures of energy substrates.

No changes in the activity of the pentose phosphate pathway enzyme, G6PDH, were detected in the smolts in the estuary as compared with the individuals kept in freshwater. These results are consistent with the data obtained in the short-term aquarium experiment and confirm the importance of maintaining the PPP activity upon change in the salinity of the environment. A low level of G6PDH activity was observed in the individuals kept in the sea (Fig. 4c). The decrease in the G6PDH during prolonged exposure to seawater may be associated with other factors that affect the overall metabolism of pink salmon smolts, such as food availability or changes in water temperature.

Thus, the results of the studies carried out on changes in the activity of enzymes of energy and carbohydrate metabolism in pink salmon larvae taken from a spawning nest in a short-term aquarium experiment and migrating smolts of pink salmon in a longterm cage experiment with changes in the salinity of the habitat indicate the presence in them of adaptive rearrangements in aerobic and anaerobic metabolism and the functioning of the pentose-phosphate pathway. Experimental data show that metabolic rearrangements associated with an increase in water salinity are characteristic of juvenile pink salmon already at the larval stage. The use of the anaerobic pathway of ATP synthesis and the maintenance of PPP functioning, as well as the plasticity of the regulation of these processes, are, apparently, among the mechanisms of biochemical adaptation of pink salmon smolts to the drastic change in the salinity of the environment, which is important in preparing pink salmon smolts for downstream migration to the sea.

\section{FUNDING}

This work was supported by the state budget, project nos. 0218-2019-0076 and 0218-2019-0081.

\section{COMPLIANCE WITH ETHICAL STANDARDS}

Conflict of interest. The authors declare that they have no conflict of interest.

Statement on the welfare of animals. All applicable international, national, and/or institutional guidelines for the care and use of animals were followed.

\section{OPEN ACCESS}

This article is licensed under a Creative Commons Attribution 4.0 International License, which permits use, sharing, adaptation, distribution and reproduction in any medium or format, as long as you give appropriate credit to the original author(s) and the source, provide a link to the Creative Commons licence, and indicate if changes were made. The images or other third party material in this article are included in the article's Creative Commons licence, unless indicated otherwise in a credit line to the material. If material is not included in the article's Creative Commons licence and your intended use is not permitted by statutory regulation or exceeds the permitted use, you will need to obtain permission directly from the copyright holder. To view a copy of this licence, visit http://creativecommons.org/licenses/by/4.0/.

\section{REFERENCES}

Churova, M.V., Shulgina, N.S., and Nemova, N.N., Activity of the enzymes of the energy and carbohydrate metabolism in the organs of the three-spined stickleback Gasterosteus aculeatus from different biotopes of the White Sea, Dokl. Biol. Sci., 2018, vol. 482, no. 1, pp. 185-187.

Le François, N.R. and Blier, P.U., Reproductive events and associated reduction in the seawater adaptability of brook charr (Salvelinus fontinalis): evaluation of gill metabolic adjustments, Aquat. Living Resour., 2003, 16, pp. 69-76.

Le François, N.R., Lamarre, S.G., and Blier, P.U., Tolerance, growth and haloplasticity of the Atlantic wolffish (Anarhichas lupus) exposed to various salinities, Aquaculture, 2004, vol. 236, nos. 1-4, pp. 659-675.

Gauthier, C., Campbell, P., and Couture, P., Physiological correlates of growth and condition in the yellow perch (Perca flavescens), Comp. Biochem. Physiol., 2008, vol. 151, pp. 526-532.

Goolish, E.M. and Adelman, I.R., Tissue specific cytochrome $c$ oxidase activity in largemouth bass: the metabolic cost of feeding and growth, Physiol. Zool., 1987, vol. 60, pp. 454-464.

Grant, A., Gardner, M., Nendick, L., Sackville, M., Farrell, A.P., and Brauner, C.J., Growth and ionoregulatory ontogeny of wild and hatchery-raised juvenile pink salmon (Oncorhynchus gorbuscha), Can. J. Zool., 2009, vol. 87, pp. 221-228.

Grant, A.M., Gardner, M.L., Hanson, L.M., Farrell, A.P., and Brauner, C.J., Early life stage salinity tolerance of wild and hatchery-reared juvenile pink salmon Oncorhynchus gorbuscha, J. Fish. Biol., 2010, vol. 77, no. 6, pp. 1282-1292.

Johansen, K.A. and Overturf, K., Alterations in expression of genes associated with muscle metabolism and growth during nutritional restriction and refeeding in rainbow 
trout, Comp. Biochem. Physiol. Part B: Biochem. Mol. Biol., 2006, vol. 144, pp. 119-127.

Kochetov, G.A., Prakticheskoe rukovodstvo po enzimologii (A Practical Guide to Enzymology), Moscow: Vysshaya shkola, 1980.

Kolb, V.G. and Kamyshnikov, V.G., Klinicheskaya biokhimiya (Clinical Biochemistry), Minsk: Belarus', 1976.

McCormick, S.D., Endocrine control of osmoregulation in teleost fish, Am. Zool., 2001, vol. 41, no. 4, pp. 781-794.

McCormick, S.D., Smolt physiology and endocrinology, in Euryhaline Fishes, McCormick, S.D., Farrell, A.P., and Brauner, C.J., Eds., 2012, pp. 199-251.

Nemova, N.N., Kyayvyaryaynen, E.I., Rendakov, N.L., Nikerova, K.M., and Efremov, D.A., Cortisol content and $\mathrm{Na}^{+} / \mathrm{K}^{+}$-ATPase activity during adaptation of juvenile pink salmon Oncorhynchus gorbuscha (Salmonidae) to changes in salinity of the environment, J. Ichthyol., 2021 (in press).

Noble, J.E. and Bailey, M.J.A., Quantitation of protein, Methods Enzymol., 2009, vol. 463, pp. 73-95.

Ruiz-Jarabo, I., Tinoco, A.B., Vargas-Chacoff, L., MartosSitcha, J.A., Rodríguez-Rúa, A., Cárdenas, S., and Mancera, J.M., Environmental salinity affects growth and metabolism in fingerling meagre (Argyrosomus regius), Fishes, 2019, vol. 4, p. 6.

Sangiao-Alvarellos, S., Laiz-Carrión, R., Guzmán, J.M., Martín del Río, M.P., Miguez, J.M., Mancera, J.M., and Soengas, J.L., Acclimation of $S$. aurata to various salinities alters energy metabolism of osmoregulatory and nonosmoregulatory organs, Am. J. Physiol. Regul. Integr. Comp. Physiol., 2003, vol. 285, pp. 897-907.

Smith, L., Spectrophotometric assay of cytochrome $c$ oxidase, Methods Biochem. Anal., 1995, vol. 2, pp. 427-434.

Soengas, J.L., Sangiao-Alvarellos, S., Laiz-Carrion, R., and Mancera, J.M., Energy metabolism and osmotic acclimation in teleost fish, in Fish Osmoregulation, Baldiserotto, B., Mancera, J.M., and Kapoor, B.G., Eds., Enfield, NH USA: Science Publishers, 2007, pp. 277-307.

Soengas, J.L., Barciela, P., Fuentes, J., Otero, J., Andrés, M.D., and Aldegunde, M., Changes in muscle carbohydrate-metabolism in domesticated rainbow-trout (Oncorhynchus mykis) after transfer to seawater, Comp. Biochem. Phys. Part B: Comp. Biochem., 1993, vol. 104, no. 1, pp. 73-179.

Tian, W.N., Braunstein, L.D., Pang, J., Stuhlmeier, K.M., Xi, Q.C., Tian, X., and Stanton, R.C., Importance of glucose-6-phosphate dehydrogenase activity for cell growth, $J$. Biol. Chem., 1998, vol. 273, pp. 10609-10617.

Tseng, Y.C. and Hwang, P.P., Some isights into energy metabolism for osmoregulation in fish, Comp. Biochem. Physiol., 2008, vol. 148, pp. 419-429.

Weisbart, M., Osmotic and ionic regulation in embryos, alevins, and fry of the five species of pacific salmon, Can. J. Zool., 1967, vol. 46, pp. 385-397.

Translated by M. Batrukova 